Annals of Tropical Research 32(2): 101-110 (2010)

\title{
Financial Modelling of Smallholder Seedling Production
}

\author{
Steve Harrison, Nestor Gregorio and Wendy Wilson
}

School of Integrative Systems, The University of Queensland, Brisbane, Qld 4072, Australia

\begin{abstract}
A financial model of smallholder forestry seedling nursery on Leyte Island has been developed as a contribution to the ACIAR project ASEM/2006/091 - Enhancing tree seedling supply via economic and policy changes in the Philippines nursery sector. Two versions of this model have been developed - one for a best management practice nursery and one for a representative smallholder nursery. This paper describes the data collection, and model development and implementation. Some implications are drawn for policy development concerning adoption of best management practice in smallholder nurseries. Possibilities for further development and application of the seedling nursery model are discussed.
\end{abstract}

Keywords: financial viability, best management practice, representative smallholder nursery, scenario analysis

\section{INTRODUCTION}

The production of seedlings of timber trees is the critical first step in the timber production supply chain. In developing countries, small-scale private and community nurseries are important sources of seedlings, often coexisting with larger government and private enterprise nurseries. Experience indicates that these small-scale nurseries often produce low quality seedlings in terms of both genetic and physical condition. A collection of papers in the combined special issue of Small-scale Forestry 7(3) on seedling nursery systems outline various problems faced by smallholder nursery operators.

Evidence from two seedling nursery surveys conducted on Leyte Island in the Philippines indicates that private smallholder and community nurseries operate intermittently or for only a relatively short time and generally with marginal profitability, e.g. see Gregorio et al. (2004) and Harrison et al. (2008). One reason for low financial returns was found to be the crowding-out effect of the provision of free seedlings by the Department of Environment and Natural Resources (DENR), local 
government units (LGUs) and other agencies. It would appear that nursery financial viability is closely linked with availability of markets for seedlings, including contracts to supply government agencies with seedlings.

Limited information is available on the financial performance of small-scale forestry nurseries and the circumstances under which these nurseries are likely to maintain financial viability. Hence, one of the activities of the ACIAR seedling enhancement project - ASEM/2006/091, Enhancing tree seedling supply via economic and policy changes in the Philippine nursery sector has been to develop financial models of small-scale nurseries, examine the circumstances under which these nurseries would be financially viable, and draw implications about measures by which nursery financial performance can be improved.

In this paper, the financial modelling method and performance criteria are first discussed, after which data collection and analysis are briefly described. Financial models for the VSU best management practice (BMP) demonstration nursery and for representative smallholder nurseries are then described, and financial performance estimates as well as sensitivity analysis are reported. Some potential improvements and uses of the financial model are discussed. Finally, some implications are drawn for developing seedling production policy.

\section{FINANCIAL ANALYSIS CONCEPTS}

The financial analysis method considers development and operation of a forestry seedling nursery as a private-sector investment project to be analysed by investment project appraisal (IPA) (as distinct from a government or socio-economic investment for which cost-benefit analysis would be appropriate) ${ }^{1}$. The annual incremental cash flows for the investment project are derived as the difference between the with-project and without-project cash flows, where cash flows are divided into capital outlays, project revenues and project operating costs, over the project life or planning horizon. Discounting by the private cost of capital is used to convert all project incremental costs and returns to equivalent values at project commencement.

In deriving incremental cash flows, capital outlays are included at the time assets are acquired, as distinct from making annual cost allowances for depreciation. Additional assets on hand at the end of the assumed project life are treated as capital inflows. Allowance may be made for taxation deductions due to project capital and operating expenditure and for taxation payable on incremental income. A more detailed description of the financial analysis method may be found in Dayanandra et al. (2002) and in Harrison and Herbohn (2007).

Discounted cash flow analysis is performed on an Excel spreadsheet, to derive financial performance criteria which indicate whether a project (in this case construction and operating of a forestry seedling nursery) is a financially viable investment. The financial performance criteria estimated include net present value (NPV) or addition to the firm's wealth, internal rate of return (IRR) or percentage rate of return on the investment, and payback period (PP) or number of years before the

${ }^{1}$ Both techniques involve discounted cash flow (DCF) analysis, but there are major differences in what cash flow items are included and how they are valued. 
investment has recouped $\operatorname{costs}^{2}$. As well as estimating financial performance, an analysis of the reliability or robustness of these estimates with respect to levels of the critical model parameters is performed; these include sensitivity, breakeven and scenario analyses.

Complexities in carrying out the analysis include determining appropriate discount rate and planning horizon, costing the operator's own resources used in the nursery (including labour and construction materials), and predicting future physical and financial parameters affecting cash flows (including seedling demand and prices which can be highly unpredictable).

\section{DATA COLLECTION AND MODEL DEVELOPMENT}

Data for model development and testing were obtained from literature review, the survey of nursery operations on Leyte Island, visits to a number of forestry seedling nurseries in Leyte by the author in September 2008, and cost records for the ACIAR ASEM 2006/091 demonstration nursery at the Visayas State University (VSU).

A detailed analysis of nursery development costs, the annual operating cost structure, and revenue from seedling sales was conducted. Aggregation of these cash flow categories was performed to simplify the financial model without excessive loss of detail. A subjective validation of the BPM financial models was conducted in November 2008, by presenting the model assumptions and outputs to a number of forestry researchers to obtain subjective feedback on model acceptability.

\section{PARAMETER ASSUMPTIONS FOR THE FINANCIAL ANALYSIS}

Financial models have been developed for a BMP nursery with an annual production capacity of 2500 seedlings, as a single production batch. Seedling production costs and prices are based on average data for gmelina (Gmelina arborea) and mahogany (Swietenia macrophylla), the two most widely grown species on Leyte tree farms. The parameter set for the financial model of a BMP nursery is presented in Table 1. Further detail about the model development and testing, and the parameter assumptions, is available in Wilson (2008).

\footnotetext{
${ }^{2}$ The payback period is derived as the number of years required for the project balances (discounted cumulative net cash flows) to become positive and remain so for the remainder of project life.
} 
Table 1. Parameter assumptions for the BMP nursery

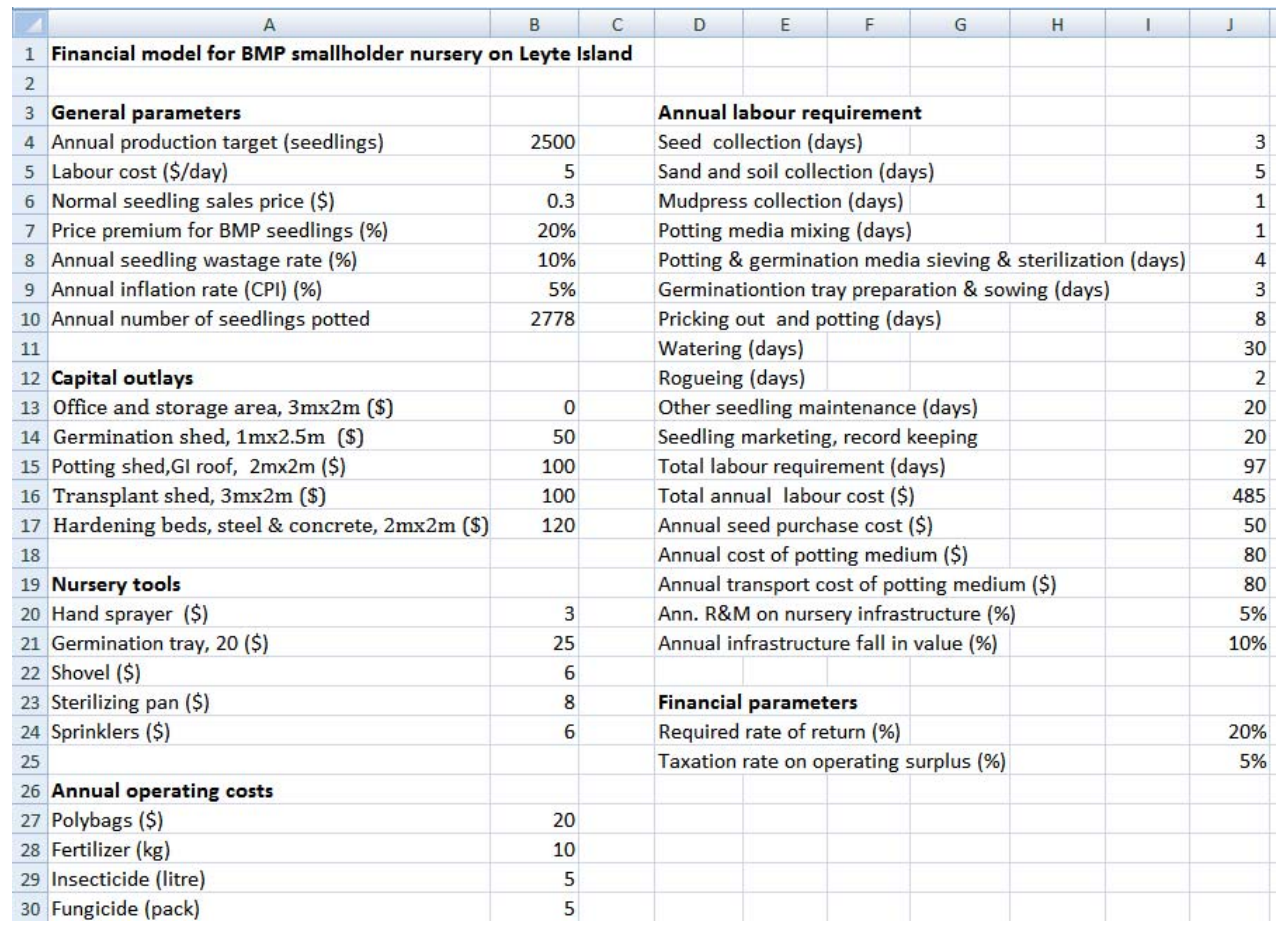

The key assumptions of this model are:

\section{THE CASH FLOW TABLE AND ESTIMATED FINANCIAL PERFORMANCE}

Annual cash flows for the BMP nursery - including nursery capital outlays, operational costs and revenue from seedling sales - have been derived, based on the parameter estimates, as presented in Table 2. The annual cost and revenue figures have been adjusted in line with the estimated inflation rate. The value of nursery capital items at the end of the 10-year planning horizon has been adjusted for both fall in market value due to ageing and increase in monetary value due to inflation, and is treated as a capital inflow in the final year.

Pre-tax annual net cash flows are estimated as nursery revenue less capital and operating costs. Revenue tax is then estimated by calculating $5 \%$ of the taxable income for the pre-tax net cash flow in each year as the amount of tax payable for each year by the nursery operator. These figures are subtracted from the pre-tax net cash flows to derive the after-tax net cash flows. Project balances (cumulative net amount of funds committed to the project) are then calculated for each year. The NPV and IRR are computed using the financial functions of Excel, and payback period is read as the number of years to achieve a positive project balance.

The positive NPV of \$567 indicates that the construction and operation of the BMP nursery increased the smallholder's wealth by this amount, after allowing for the cost 
of own or hired labour and other inputs. The IRR of just over $50 \%$ indicates that rate of return on the investment is well above the cost of capital of $20 \%$ per annum. The first positive project balance is in year 3 , indicating a payback period of four years.

While the IRR seems particularly high and the payback period very short, this outcome is influenced by the relatively small capital outlay relative to annual operating cost (especially labour) and annual revenue. Extremely high IRR values are often encountered in projects with low capital intensity, and are not particularly meaningful. The NPV is the most useful financial performance indicator in this situation. A positive NPV (after allowing an adequate reward for the nursery operator's labour) make this a financially viable project.

Table 2. Cash flow table for BMP nursery model

\begin{tabular}{|c|c|c|c|c|c|c|c|c|c|c|c|c|}
\hline 1 & A & в & c & D & E & $\mathrm{F}$ & G & H & 1 & J & $\mathrm{k}$ & L \\
\hline 32 & Cash flow table & & & & & & & & & & & \\
\hline 33 & Year & 0 & 1 & 2 & 3 & 4 & 5 & 6 & 7 & 8 & 9 & 10 \\
\hline 34 & Inflation factor & 1.0000 & 1.0500 & 1.1025 & 1.1576 & 1.2155 & 1.2763 & 1.3401 & 1.4071 & 1.4775 & 1.5513 & 1.6289 \\
\hline \multicolumn{13}{|c|}{ 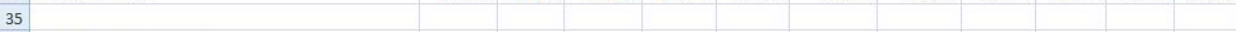 } \\
\hline 36 & Capital outlays (PhP) & & & & & & & & & & & \\
\hline 37 & Nursery infrastructure (PhP) & 370 & & & & & & & & & & -210 \\
\hline 38 & Nursery tools and equipment (PhP) & 48 & & & & & & & & & & \\
\hline 39 & Total capital outflows (PhP) & 418 & 0 & 0 & 0 & 0 & 0 & 0 & 0 & 0 & 0 & -210 \\
\hline \multicolumn{13}{|l|}{40} \\
\hline 41 & Operating Costs (PhP) & & & & & & & & & & & \\
\hline 42 & Nursery labour (PhP) & & 509 & 535 & 561 & 590 & 619 & 650 & 682 & 717 & 752 & 790 \\
\hline 43 & Polybags (PhP) & & 21 & 22 & 23 & 24 & 26 & 27 & 28 & 30 & 31 & 33 \\
\hline 44 & Potting medium (PhP) & & 84 & 88 & 93 & 97 & 102 & 107 & 113 & 118 & 124 & 130 \\
\hline 45 & Fertilizer, insecticide and fungicide (PhP) & & 21 & 22 & 23 & 24 & 26 & 27 & 28 & 30 & 31 & 33 \\
\hline 46 & Transport (PhP) & & 84 & 88 & 93 & 97 & 102 & 107 & 113 & 118 & 124 & 130 \\
\hline 47 & Repairs and maintenance (PhP) & & 22 & 23 & 24 & 25 & 27 & 28 & 29 & 31 & 32 & 34 \\
\hline 48 & Total operating costs (PhP) & & 741 & 778 & 817 & 858 & 901 & 946 & 993 & 1043 & 1095 & 1150 \\
\hline \multicolumn{13}{|l|}{49} \\
\hline 50 & Nursery revenue (PhP) & & & & & & & & & & & \\
\hline 51 & Expected seedling sales price (PhP) & & 0.38 & 0.40 & 0.42 & 0.44 & 0.46 & 0.48 & 0.51 & 0.53 & 0.56 & 0.59 \\
\hline 52 & Annual revenue from seedling sales (PhP) & & 945 & 992 & 1042 & 1094 & 1149 & 1206 & 1266 & 1330 & 1396 & 1466 \\
\hline \multicolumn{13}{|l|}{53} \\
\hline 54 & Pre-tax net cash flow (PhP) & -418 & 204 & 214 & 225 & 236 & 248 & 260 & 273 & 287 & 301 & 526 \\
\hline 55 & Taxation payable (PhP) & & 10 & 11 & 11 & 12 & 12 & 13 & 14 & 14 & 15 & 16 \\
\hline 56 & After tax net cash flows (PhP) & -418 & 194 & 203 & 213 & 224 & 235 & 247 & 259 & 272 & 286 & 511 \\
\hline 57 & Project balance (PhP) & -418 & -257 & -115 & 8 & 116 & 211 & 293 & 366 & 429 & 485 & 567 \\
\hline 58 & Year of change to positive project balance & & & & 3 & & & & & & & \\
\hline 59 & Net present value (NPV) (\$) & 567 & & & & & & & & & & \\
\hline 60 & Internal rate of return (IRR) (\%) & $50.4 \%$ & & & & & & & & & & \\
\hline 61 & Payback period (years) & 3 & & & & & & & & & & \\
\hline
\end{tabular}

\section{SENSITIVITY, BREAKEVEN AND SCENARIO ANALYSIS}

There is obviously a high level of uncertainty surrounding the financial performance estimates, and further refinement of these estimates would be desirable. Due to the high uncertainty, tests have been undertaken to examine the impact of changes in parameter levels on financial performance. The critical parameters identified for the further analysis include discount rate, labour cost, seedling cost, seedling price, and quantity of seedlings sold.

\section{The NPV Profile}

The NPV profile or graph of NPV against the discount rate for the nursery investment is presented as Figure 1. The profile crosses the horizontal axis at a cost of capital of about $50 \%$, which is consistent with the IRR estimate. The curve is well 
behaved (consistently downward sloping) indicating there are no problems with multiple or non-existent IRR values.

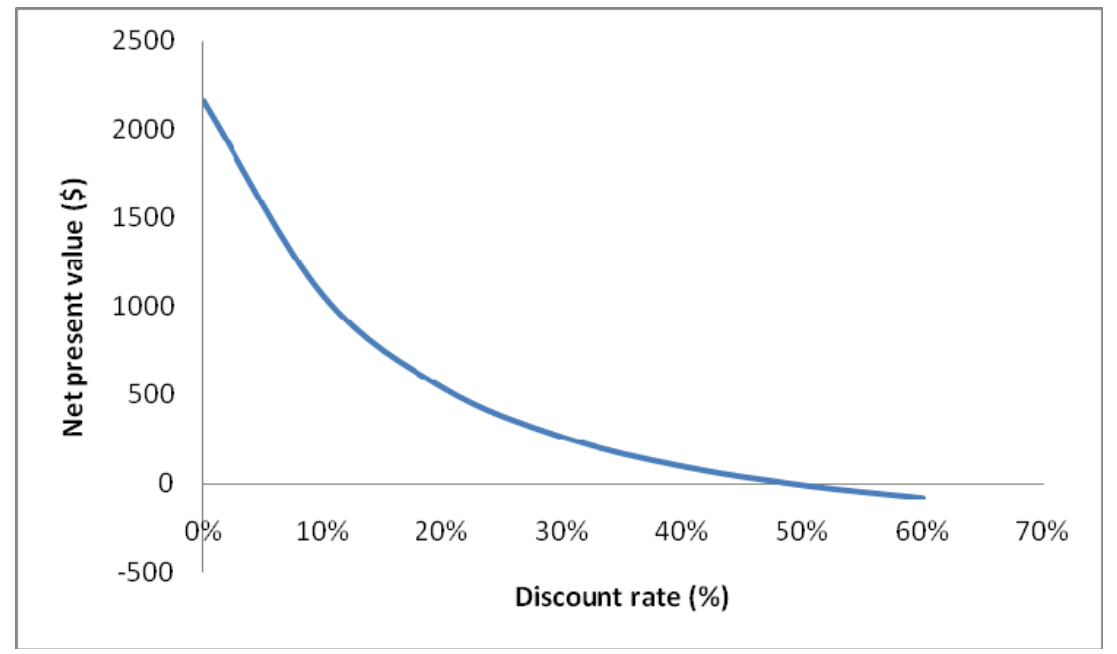

Figure 1. NPV profile for nursery investment project

\section{Breakeven Analysis}

The Goal Seek function of Excel was used to calculate the levels of the critical parameters for which the estimated NPV is exactly zero, i.e. the breakeven parameter levels. Results are presented in Table 3. Labour cost could increase to a little over \$6/hour, or the market seedling price could fall to 26 cents and the project still break even. Levels of other parameters are less critical: the premium for BMP seedlings could fall to about $5 \%$, a higher inflation rate actually increases the NPV, and a very high taxation rate could be accommodated (because this only applies to the difference between revenue and cost).

Table 3. Breakeven analysis of the BMP smallholder nursery investment

\begin{tabular}{lcc}
\hline Parameter & Current level & Breakeven level \\
\hline Labour cost (\$/day) & 5 & 6.19 \\
Normal price (\$/seedling) & 0.3 & 0.26 \\
BMP price premium (\$/seedling) & $20 \%$ & $4.6 \%$ \\
Inflation rate (\%) & $5 \%$ & $-16 \%$ \\
Taxation rate (\%) & $5 \%$ & $62 \%$ \\
\hline
\end{tabular}

\section{Sensitivity analysis}

A sensitivity analysis was undertaken for the BMP nursery model in which levels of each of the critical parameters - expected wage rate, normal seedling sale price, premium for BMP seedlings, inflation rate and taxation rate, were varied by plus and 
minus 50\%. The changes in NPV for these changes in parameter levels are summarized in Table 4.

Table 4. Sensitivity analysis for seedling nursery investment

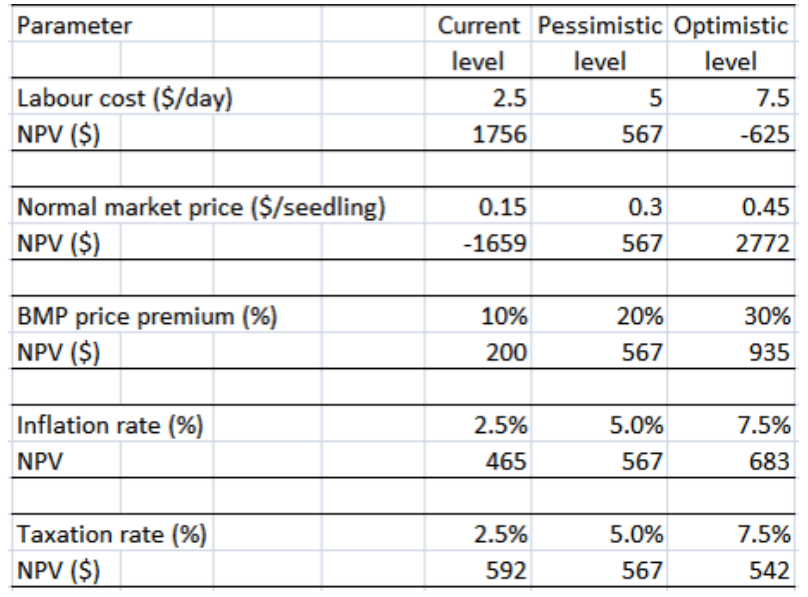

As indicated in this table, a higher labour cost or a lower normal seedling market price would potentially make the NPV negative, but the NPV is relatively robust to changes in levels of the other parameters.

\section{Scenario Analysis}

A scenario analysis has been carried out for the nursery investment. Three parameters - those for which the NPV was found most sensitive - have been simultaneously adjusted by $20 \%$ upwards or downwards to define optimistic and pessimistic scenarios. In the pessimistic case, the wage rate is increased and the normal sale price and BMP premia have each been reduced by $20 \%$. In the optimistic scenario the adjustments are in the opposite direction. The scenario analysis table (automatically generated as a separate sheet in Excel) is presented as Table 5.

Table 5. Screenshot of scenario analysis of nursery investment with respect to three critical parameters

\begin{tabular}{lccc}
\hline Scenario summary & $\begin{array}{c}\text { Current } \\
\text { values: }\end{array}$ & $\begin{array}{c}\text { Pessimistic } \\
\text { scenario }\end{array}$ & $\begin{array}{c}\text { Optimistic } \\
\text { scenario }\end{array}$ \\
\hline Changing cells: & & & \\
\hline Wage rate (\$/day) & 5 & 6 & 4 \\
Normal seedling price (\$) & 0.3 & 0.24 & 0.36 \\
BMP price premium (\%) & $20 \%$ & $16 \%$ & $24 \%$ \\
\hline Result cells: & & & \\
\hline NPV & 543 & -947 & 2081 \\
\hline
\end{tabular}


It is apparent in Table 5 that for even modest simultaneous changes in uncertain parameter levels the NPV estimates vary widely, with the pessimistic scenario indicating a financial loss from the project. This suggests that effort in obtaining more precise estimates of parameter levels may be warranted.

\section{FINANCIAL EVALUATION OF THE REPRESENTATIVE SMALLHOLDER NURSERY}

The scenario analysis facility provides a simple method to gain insights into the impact of changes in nursery design or operation on financial performance. A reasonably realistic scenario for a typical smallholder nursery would appear to be a requirement for less skilled labour at a lower wage rate (say \$4/day), no premium for seedling quality, and the operator does not pay any revenue tax. The changes in parameters can be used to define a smallholder representative nursery scenario, as in Table 6 .

Table 6. Financial performance for a representative smallholder nursery, treated as a scenario in relation to the BMP nursery

\begin{tabular}{lcc}
\hline Scenario summary & Current values & $\begin{array}{c}\text { Representative } \\
\text { smallholder nursery }\end{array}$ \\
\hline Changing cells: & & \\
\hline Wage rate (\$/day) & 5 & 4 \\
Price premium (\%) & $20 \%$ & $0 \%$ \\
Inflation rate (\%) & $5 \%$ & $0 \%$ \\
\hline Results cells: & & \\
\hline Net present value (\$) & 567 & 344 \\
Internal rate of return (\%) & $50.4 \%$ & $38.9 \%$ \\
\hline
\end{tabular}

Under these assumptions, the NPV is reduced, but is still positive. Other changes such as less costly nursery buildings and a higher seedling mortality rate could similarly be included in the analysis. What would be more difficult to include is the greater performance of the seedlings on outplanting, because this is not part of the 'nursery project'.

\section{DISCUSSION}

A financial analysis using the best available information on nursery capital outlays, operating costs and seedling sale revenue indicates that a small seedling nursery adopting best management practice and obtaining a price premium for seedlings would be a financially viable investment. The financial returns could be expected to be slightly higher than those of a representative smallholder nursery using typical current technology.

The model reported here draws on capital outlays recorded in constructing a BMP demonstration nursery at the Visayas State University in Leyte. Some validation was 
applied to the financial model, using the subjective approach of asking forestry experts whether they agreed with the model outputs (cost parameters and financial performance statistics) given the model inputs (capital outlays and other assumptions). While obtaining subjective opinion is the only viable method of model validation in the short run, it should be noted that in practice confidence is built up in models over time as they are used by more people and progress through a number of versions. The model reported here is a relatively simple one, and further refinement is required, for example with respect to the relationships between operating costs and seedling output for nurseries of differing sizes, and the cost differences in producing seedlings (or using wildlings) between tree species.

Development of future models will require the input of the stakeholders for whom the model is specifically being designed. Financial models required for use by forestry researchers and academics with an understanding of financial modelling or the science of forestry could incorporate more complex detail compared to simplified models designed for use by extension providers to smallholder nursery operators. Further research is being carried out on financial analysis of BMP nurseries for producing seedling for forestry projects, and in particular the impact of nursery size on cost of seedling production and on accessibility of nurseries to smallholders.

There is a need to develop a generic nursery financial model. A model such as that described above could be used as a prototype, but with an option for users to override the default parameter values with their own estimates. In this way, the model would be available to other users, to apply to situations relevant to them. That is, the model could be used as a decision-support tool for use by various agencies and individuals, and for various nursery situations (e.g. in terms of production volume, species grown, labour productivity and market conditions).

An alternative form of analysis for research purposes, for which a prototype model has been developed, involves risk simulation of critical cash flow parameters, and in particular seedling demand and price. Probability distributions are estimated for the critical parameters, and Monte Carlo (random) sampling is performed for each year of the project life, from these distributions, with a separate DCF analysis carried out for each random set of parameter values over the project life. Finally, the estimated values of NPV are ranked in order of increasing magnitude, and a relative frequency distribution is derived and graphed. In this way, the probability distribution of financial performance can be estimated, for given likelihoods of seedling sales levels (or contracts) and seedling prices.

\section{CONCLUDING COMMENTS}

The methodology of financial investment appraisal using the discounted cash flow analysis technique on an Excel spreadsheet provides an effective approach to evaluation of the financial viability of forestry nursery investment 'projects'. Care is needed to apply this method of analysis correctly, and to make transparent the assumptions of the analysis, for example with regard to discount rate, assumed project life, treatment of inflation, and inclusion of salvage values of capital items. Additional insights into investment viability can be gained through sensitivity, breakeven and scenario analysis. Applying this methodology to a small-scale nursery designed to 
utilize best management practice in seedling production indicates that the nursery would be a viable investment, but the net present value would be sensitive to the wage rate or labour opportunity cost of the operator's labour, and to the seedling sale price achieved.

The scenario analysis feature of MicroSoft Excel provides a means to compare a BMP and typical smallholder nursery. Preliminary analysis suggests that the lower costs and lower product price of a representative smallholder nursery may lead to a similar or slightly lower financial performance to that of a BMP nursery. However, this analysis does not take into account the likely improved growth performance of outplanted seedlings and hence financial benefits for tree farmers, which could be substantial. From a forest policy perspective, the analysis supports the call for introducing seedling nursery certification to provide assurance of improved seedling quality.

\section{REFERENCES}

DAYANANDRA, D., IRONS, R., HARRISON, S., HERBOHN, J. and P. ROWLAND. 2002. Capital Budgeting: Financial Appraisal of Investment Projects. Cambridge University Press, Cambridge.

GREGORIO, N.O., HERBOHN, J.L. and S.R. HARRISON. 2004. Small-scale forestry development in Leyte, the Philippines: the central role of nurseries. Small-scale Forest Economics, Management and Policy. 3(3): 337-351.

HARRISON, S. In press. Deriving the discount rate for seedling nurseries and other livelihood projects, Enhancing Seedling Supply via Economic and Policy Changes in the Philippines Nursery Sector (ACIAR Project ASEM 2006/091, Proceedings of the End-of-Project Workshop, Visayas State University, Baybay. School of Integrative Systems, The University of Queensland, Brisbane and Australian Centre for International Agricultural Research.

HARRISON, S. and J. HERBOHN. 2007. Financial and Economic Research Methods for Natural Resource Managers Training Workshop. Proceedings of a Training Workshop for ACIAR Project Staff. Heritage Hotel, Manila, 9-13 January 2007. School of Natural and Rural Systems Management, The University of Queensland, Brisbane and Australian Centre for International Agricultural Research, Brisbane.

HARRISON, S., GREGORIO, N., HERBOHN, J. and P. DARGUSCH. 2008. Designing and implementing best management practice in smallholder forestry nurseries. Paper presented at the FORTROP 2 Forestry Conference, Kassetsart University, Bangkok.

WILSON, W. 2008. Applying financial analysis to forestry seedling nursery enterprises on Leyte Island, the Philippines. M.Agribus. thesis, The University of Queensland, Brisbane. 